\title{
Character Education for Teenagers Through Motivating Sentences (Character Themes/Values Found in Teenagers' Motivation Sentences/Writing)
}

\author{
Abdillah Nugroho* \\ Department of Indonesian Education \\ Universitas Muhammadiyah Surakarta \\ Surakarta Indonesia \\ an264@ums.ac.id,
}

\author{
Agus Budi Wahyudi \\ Department of Indonesian Education \\ Universitas Muhammadiyah Surakarta \\ Surakarta Indonesia \\ , Agus.B.Wahyudi@ums.ac.id
}

\author{
Adyana Sunanda \\ Department of Indonesian Education \\ Universitas Muhammadiyah Surakarta \\ Surakarta Indonesia \\ adyana_sunanda@ums.ac.id
}

\author{
Atiqa Sabardila \\ Department of Indonesian Education \\ Universitas Muhammadiyah Surakarta \\ Surakarta Indonesia \\ Atika.Sabardila@ums.ac.i
}

\author{
Naimul Faizah \\ Department of Indonesian Education \\ Universitas Muhammadiyah Surakarta \\ Surakarta Indonesia \\ naimulfaizah125@yahoo.co.id
}

\begin{abstract}
This research aimed at analysing teenagers' character education through motivating sentences and further identifying the themes of motivating sentences composed by the teenagers. The study belonged to qualitative research. Objects of the study consisted of the texts of motivating sentences written by the teenagers. Data cellection was done through documentation of the students' writings related to motivating sentences. Method of the data analysis was carried out through descriptive technique and a content analysis was applied to examine the data collected. The findings show that the motivating sentences arranged by the students or teenagers contained some character educations theme such as struggle, education, ambition, family, divinity and care.
\end{abstract}

Keywords-character, education, sentences, motivation, teenager

\section{INTRODUCTION}

The success of the education process can be seen from the success of the character building of the students. The success of the education process is not merely seen from the mark they obtain but is also viewed from the success of creating a competent young generation who are not only mastering science and technology but also having wholly positive characters. It is in line with the idea written in UndangUndang Dasar Republik Indonesia 1945 (The Indonesian National Constitution 1945) in which one of them is aimed at realizing the excellence of the nation cognitively, emotionally and socially.

However, the realization of teenagers with such ideal characteristics often encounter many obstacles. The problems coming from the social environment, family, and society will directly and indirectly give an impact on the teenagers' development. In fact in the research location at a private Junior High School in the city of Surakarta, Indonesia it was found that there were so many students that need very specific attention and also treatment. It was found that they posted inappropriate photos in their Facebook accounts related to their relationship with the opposite sex. Some of them were known to come from a broken family which might affect them. The bad home situation worsened their condition.

In addition to this, what is observable these days is the decreasing of teenagers' politeness and respect towards their parents. Today's teenagers have seemingly lost their respects towards the elderly. Newspaper reported teenagers challenged their teachers to fight or spoke impolitely and disrespectfully to their teachers. Further, there are also reports on the increasing number of bullying cases by friends which cause deep trauma on the victims. These cases indicate the decreasing of love and care characters. It requires more thoughts and proper solution.

Seeing these phenomena, the researchers needed to do a research concerning with the character education for the teenagers through motivating sentences. By creating such motivating sentences, psychologically a process of character formation might occur in their mind when they read and understand the motivating sentences they created.

\section{LITERATURE REVIEW}

\section{A. Nature of Sentence}

Chaer (2009) states that the sentence structure in a composition consists of 3 namely simple sentence, expanded sentence, and inversion sentence. Furthermore, Sukini (2010) explains that the simple sentence contains a basic information and has not yet been changed. The changes can be in an adding element such as adverbial clause, subjective complement, predicate, object, and completion. Parera (2009) finds that the expanded sentence or clause is a sentence having 
the potency to expand and be able to return back to its base. Chaer (2009) adds that the inversion sentence is a successively different function.

Writing a sentence strongly relates to the term diction. Diction or word choice has an important role in creating the nuance of meaning that the writer in intended to. A good diction is the diction that fulfills the requirements such as accuracy (showing an idea accurately), rightness (suitable with the language rule), and appropriate use (Wijayanti, 2013).

\section{B. Motivation}

KKBI (2012) defines motivation as firstly a push coming from the self consciously and unconsciously to do an action with a certain goal. Secondly an effort that can make someone or a particular group of people do something because they want to achieve their goal or get satisfaction for their action.

\section{Language of Teenager}

Harimansyah (2015) explains that teenagers were competent speakers and were not closed to their language choice. When absorbing the language by developing vocabulary and its stylistically distant, they control them fully. They often choose words different from the adult. It causes many varieties of language. The variety of language made by the teenagers is called the teenager's language. By using various language, the teenagers hope that there is a different perspective in themselves compared to their friends. Some of them use the language as manifestation of their creativity needed developing to reach their satisfaction.

\section{Theme Classification}

A theory focused on theme of teenager's motivation has not been found. Concerning this, the researchers tried to present a theme classification of poem as a closer discussion instead. Nurgiyantoro (2010) exposes three themes in a poem as follows:

\section{1) Theme of Parents and Teacher}

Commonly children are so close to their parents, especially mother, that there are many poem themes inspired by their parents. The parents seemingly become children's obsession and emotional expression. Usually the theme concerns with affection, care, love, longing, amazement, gratitude and so forth showing the closeness of a child to his mother.

\section{2) Theme of Animal and Nature Environment}

One of the themes raised in children's poem is the theme nature environment. The intended animals consist of chickens, birds, cats, dogs and so forth. By using those themes, the children get emotional experience and become obsessed to express their feelings through poem

\section{3) Religious theme}

There're so many religious theme found in a child's poem containing praise, admiration toward God' greatness, prayer, good deeds to all creature of God, and so on. This theme is also able to bring the emotion up so that the children can express their emotion in the form of poem.

There studies that are relevant with the present research. Erfanto (2013) researched theme and mandate in poem ontology of Kerikil Tajam dan Yang Terhempas dan Yang Putus. The research found the poem containing the themes of social life, such as condolence (Nisa poem), the powerless (Penghidupan poem), struggle (Diponegoro poem), and what not. The mandate in Chairil Anwar's poem was suggestion to surrender to and glorification to God the almighty, struggle to reach the independence, staying away from revenge, and being always honest.

Suhardi and Chandra (2012) did a research on the poem theme of Gusmarni Zulkifli. The research result found 10 themes in the poem namely (1) female figure hoping the lover and ending with disappointment, (2) feeling of disappointment to the lover because of lacking of attention, (3) obstinacy of woman facing her given life, (4) longing to meet Allah (God), (5) feeling of scare always haunted after being far from the parents, (6) feeling of compassion to meet the parents (mother), (7) feeling of high confidence that her lover is impossibly seduced by another woman, (8) feeling of scare to face the life, (9) longing feeling to the mother, and (10) feeling of grief when mourning.

Mardlotillah (2011) researched on the processing of theme and structure of the teenagers' poem at grade VII of a Junior High School. The research result showed that the students used three patterns when processing the theme, namely the pattern of observation, field experience, and contemplation. Concerning with the structure of the poem on its sound elements, the students did not use a certain poem pattern because the poem written by the students is a free poem. For sound variety, they dominantly used euphony. Meanwhile for word elements, the students used base, utterance, and symbol. The poem typography tended to be in square forms.

Indarwanto (2010) did a research on theme and mandate as well as the expressive, referential, and poetic function in the poem collection of Le De Joie by Louis Aragon. The result showed that firstly Soif de l'Quest had a theme of foreign culture imitation, and Chambre Garnie had a theme of first love, and La Belle Italienne had a theme of beauty of the Italian woman. Secondly the three poems had a mandate to love culture of the nation, be sportive on love, be patient because of love rejection. Thirdly the expressive function contained expression and ideas of the speaker, and referential function discussed life style, metropolitan girls, and Italian women. The poetic function of the three poems is a manifestation of beauty of the poem shown with the use of sound playing.

\section{RESEARCH METHOD}

- This research was carried out by describing teenagers' motivating words semantically and pragmatically. Based on this formulation, the research belonged to qualitative research 
because it concerned with words, phrases, and motivating sentences. It was in line with the opinion of Moleong (2011:11) that the data collected in the form of words, phrases, pictures not in the form of numbers belong to a qualitative research.

Objects of the research were words, phrases, or sentences showing teenagers' motivating sentences. The primary data of this research were in the form of themes in teenagers' motivating words that could be found in the form of words, phrases, and sentences. Sources of the data were the sentences written by the students of a Junior High School in Surakarta, Indonesia.

The data collection was carried out by making documents of the students' writings in terms of motivating sentences especially those containing specific themes. The validity of the data was ensured by a triangulation technique of sources and researchers. The researchers collected the data as many as possible. Later on the data collected were discussed together with the research team.

Technique of the data analysis used the equivalent method. This method is a method in which its determinant tool is in out, separated, does not belong to the part of the language involved. The equivalent method used was the referentially equivalent method with the language referential determinant tool. In addition to this, the reading marking technique and focus group discussion were also conducted.

\section{RESULTS AND DISCUSSION}

\section{A. Results}

Based on our analysis, it was found that there were seven themes in the teenagers' motivating sentences. They are presented as follows:

\section{1) Theme of Struggle}

There were so many struggle themes found in teenagers' motivating sentences. The dominant struggle theme indicated that the youth were courageous and had the desire to get what they wanted. The followings were examples of sentences showing the theme of struggle.

a) Urip kui koyo dolanan lompatan, diuntang-antingke Sok neng duwur sok neng ngisor

Sok terkadang nganggo kesrimpet

Sok ngasi tibo

Tapi ora pareng nangis.

[Life's like a jumping around game, got thrown here and there. Sometimes above, sometimes below. Sometimes I got tripped, until I fall. But I don't want to cry.] (A. S. 9B)

The motivating sentence could be understood in the motivating sentence $[a]$. In the Javanese motivating sentence, the student analogized his life with a jumping game. Life was described with the ups and downs, not only happiness but also grief. It could be seen in the sentence "Sok neng nduwur sok neng ngisor." Sometimes people live in a bad condition and sometimes in a good one. According to the student, people should live the life with sincerity and full of struggle.

2) Theme of Education

The following examples were the motivating sentences having theme of education.

a) Setinggi-tinggi ilmu yang kita dapat, pasti melebihi gunung. Belajar, belajar, belajar.

[As high as we get the knowledge, it must be higher than a mountain. Study, study, study.]

$$
\text { (L.A.D.N. A) }
$$

In the motivating sentence $[a]$, the student described knowledge as a bigger form than a mountain. In this case, the intended form was not a concrete form but the benefit for people having knowledge was higher than a mountain.

Person having knowledge, can do a great thing, create a plane and train that can cut across the mountain. Surely it can be done if a person has knowledge (education). Later on, the student gave an emphasis on sentence "Study, study, and study." This student believed that perseverance in study is needed in order to master the knowledge. It can be concluded that these sentences have an education theme.

\section{3) Theme of Ambition}

The following motivating sentence example had an ambition theme.

a) Kejarlah mimpimu dan jadikanlah suara cemoohan tersebut menjadi sebuah tepuk tangan.

[Reach your dream and turn the voices of mockery into hand clapping.] (S.S.D 8A)

The motivating sentence above use the term dream to refer to the term ambition. The word dream is accompanied by the lingual unit "Kejarlah" which meant to do effort for making the ambition comes true. The word kejar means "run after." Then the meaning of "berlari" wasis to step quickly having connotative meaning of highly spirited or cheering up. It may mean that dream or ambition a person reaches must be struggled with a high spirit. In addition, when struggling for an ambition, a person does not care of mockery from other people. The people's mockery should become the spirit to reach the dream.

4) Theme of Family

The following motivating sentences show the theme of family.

a) Aku ingin membuat ibuku tertawa, bahagia, dan tersenyum selalu karena surga di telapak kaki $i b u$,

[I want to make my mother laugh, feel happy, and always smile because heaven lies beneath her feet.] (E. W. 8A)

Here the student showed her intention to make her parents happy, especially her mother. It can be found in the part " $A k u$ ingin membuat ibuku tertawa, bahagia, dan tersenyum..." It shows the student's strong feelings (love) towards her mother 
and that she wanted to do everything to make her mother happy. She also added "karena surga di telapak kaki ibu" which displays her belief that she made a good deed if she made her mom happy (heaven is beneath her mother's feet). She realized that she needed to be dedicated to her mother and made respecting and making parents' happy as an obligation.

\section{5) Theme of Divinity}

The following is the motivating sentence with the theme of divinity.

\section{a) Becik ketitik olo ketoro} Innallaha ma'ashabirin [Goodness will be noted (rewarded), badness will be exposed. Indeed, Allah (God) is with patient people] (A. 9C)

The Javanese motivating sentence means that the truth that was covered will be exposed eventually and will. The sentences are continued with an Arabic quotation meaning that Allah be with the patient people. This sentence showed the theme of divinity in the motivating sentence. The intention of the student composing both sentences was that in life people should be patient and live the life in a good way in order that their lives was blessed by Allah.

\section{6) Theme of Ambition}

The following motivating sentence contain theme of ambition.

a) Janganlah melihat ke belakang, melihatlah ke depan.

Lelah belajar pada waktu kecil lebih

baik daripada lelah hidup waktu

besar nanti.

[Don't look back, look ahead. Being

exhausted from studying when you

are a child is better than being

exhausted for living when you are

older] (A. 9B)

These sentences contain the character of being visionary "Janganlah melihat ke belakang, melihatlah ke depan [Don't look back, look ahead..]". It can be concluded that according to this student, the future is very important to be thoroughly prepared. The past is used as a lesson (experience) for reaching a better future. In addition to this, the student gave an emphasis that "Lelah belajar pada waktu kecil lebih baik daripada lelah hidup waktu besar nanti" which literally means work hard now so a person doesn't face a difficult life at older age due to being lazy at youth. Difficulties accompanied bby hard work impact the future.

\section{7) Theme of Care}

The motivating sentence with the theme of care can be seen in the following:

a) Warna hidup itu lebih berarti jika kita berbagi, untuk orang yang kurang mampu mengerti dan tak tahu makna memahami di dalam sebuah arti!!! [The color of life is more meaningful if we share it with others who do not understand and do not know how to interpret meaning."] (F. I. P.R. 9A)

Here, the student used diction "warna hidup" which means everything in life, such as goodness and happiness will be meaningful if people care and are sincere in sharing "[The color of life is more meaningful if we share with others.]".

The student also added the people who need to be shared are those who do not understand and do not know how to interpret meaning. Relating to the writer as the student of Junior High School, it can be understood that to share may mean that caring others means sharing with friends who do not understand the lesson at school. In the teaching learning process, the students have different abilities, some are quick and others are slow. According to her, life is more meaningful if friends share knowledge each other.

\section{B. Discussion}

This study has similarities and differences with some previous researches. The research has similarity with the research done by Erfando in analyzing theme. However, Erfando (2013) focuses on theme of Chairil Anwar's Kerikil Tajam dan Yang Terhempas dan Yang Putus, while this research focuses on theme on the motivating sentence. Erfando found that theme of social life such as sorrow (poem of Nisan), helpless (poem of Penghidupan), struggle (poem of Diponegoro), and many others. The moral message of Chairil Anwar's poems contains suggestion to devote to Allah (God), glorification to Allah, struggle to fulfill the independence, staying away from revenge, and being always fair (just).

Another study by Suhardi and Candra (2012) made use of Gusmani Zulkifli' poems as the object. They focused on on teenagers' motivating sentences. The research result found 10 themes in the poem namely (1) female figure hoping the lover and ending with disappointment, (2) feeling of disappointment to the lover because of lacking of attention, (3) obstinacy of woman facing her given life, (4) longing to meet Allah, (5) feeling of scare always haunted after being far from the parents, (6) feeling of compassion to meet the parents (mother), (7) feeling of high confidence that her lover is impossibly seduced by another woman, (8) feeling of scare to face the life, (9) longing feeling to the mother, and (10) feeling of grief when mourning.

Mardlotillah (2011) also researched about theme. She researched teenagers' poem at at grade VII of a Junior High School in East Java. In Mardlotillah's research, it is revealed that the students used three patterns when processing the 
theme, namely the pattern of observation, field experience, and contemplation. Concerning with the structure of the poem on its sound elements, the students did not use a certain poem pattern because the written poem by the students is a free poem. For sound variety, they dominantly use euphony. Meanwhile for word elements, the students used base, utterance, and symbol. The typography of the poem tended to be in square form.

The last, it was found the same study cencerning with theme on Indarwanto's research (2010). The difference lies on object of the study. The result of the research showed that firstly Soif de l'Quest had a theme of foreign culture imitation, and Chambre Garnie had a theme of first love, and La Belle Italienne had a theme of beauty of the Italian women. Secondly the three poems had a mandate to love culture of the nation, be sportive on love, be patient in times of love rejection. Thirdly the expressive function contained expression and ideas of the speaker, and referential function discussed lifestyle, metropolitan girls, and Italian women. The poetic function of the three poems is a manifestation of beauty of the poem shown with the use of sound playing.

The present research found seven themes of the motivating sentences. Firstly the teenagers' motivating sentence contains theme of struggle. The sentences written by them describes something that is closer to their daily activities. One of them is struggle and sooth for the teenagers to face their problems.

Secondly, the motivating sentence have theme of education. The world of education is one of the closest thing with the youth. They study from childhood until teenagers. From the school, they will get many knowledge giving benefit for their future. Because of that, theme of education and learning become the central theme written by them.

Thirdly, the motivating sentence contains theme of ambition. Indirectly this theme has a close relationship with the previous theme, namely education. They study seriously to reach their ambition. Their desire to make their ambition comes true leads them to study and work hard.

Fourthly, the motivating sentence has theme of family. It indicates there is a close relationship among children, family, and parents especially mother. The motivating sentence becomes a media for the youth to express their feeling of affection and love to their parents. In addition to this, the motivating sentence also becomes the media to express their hopes towards their parents.

Fifthly, the motivating sentence also shows theme of divinity. It also indicates the teenagers' consciousness towards religious values. It also reflects that values of goodness in religion becomes an important part for them.

Sixthly, the motivating sentence shows theme of the future. It can be understood that their future becomes their life focus. It means that the struggle and hard work in the past are always oriented for the success of their future. It means that the future needs to be prepared well.

Seventhly, the motivating sentence contains theme of care. It can be concluded that to share may mean caring to those who do not understand the lessons at school. In the teaching learning process, the students had different abilities and achievemt. Some were quick and others were slow. Due to this fact, the writer of the sentence said that the color of life in school is more meaningful if we share knowledge with others

\section{CONCLUSION}

Based on the analysis, it can be concluded that there were seven themes of motivating sentences namely struggle, education, ambition, family, divinity, future, and caring. All themes found in motivating sentence reflected something close to them, for instance spirit of struggle in solving the problems or motivation to reach their future. In addition to that, it was also found reflections of their daily activities at school as well as at home. It also reflected their willingness to reach their brighter future and also desire to share with others.

\section{ACKNOWLEDGMENT}

This work was supported by The Ministry of DIKTI of Republic of Indonesia through the scheme of PDUPT.

\section{REFERENCES}

Arikunto, S. (2010). Prosedur penelitian. Jakarta: Rineka Cipta.

Chaer, A. (2009). Psikolinguistik: Kajian teoretik. Jakarta: Rineka Cipta.

Departemen Pendidikan dan Kebudayaan. (2012). Kamus besar bahasa Indonesia. Jakarta: Balai Pustaka.

Erfando, D. (2013). Analisis tema dan amanat antologi puisi Kerikil Tajam dan Yang Terhempas dan Yang Putus Karya Chairil Anwar. Artikel E-Journal. Tanjungpinang: Universitas Maritim Raja Ali Haji.

Harimansyah, G. (2015). Pilihan bahasa remaja dalam perspektif umur dan lintas generasi. Badan Bahasa Kemdikbud.

Indarwanto, T. (2010). Tinjauan tema, amanat, fungsi ekspresif, referensial, dan puitik dalam kumpulan puisi Le Feu de Joie Karya Louis Aragon. Skripsi. Semarang: Universitas Negeri Semarang.

Mardlotillah, F. (2011). Analisis pengolahan tema dan struktur puisi remaja: Studi pada siswa kelas VII SMP Muhammadiyah 10 Bungah, Kabupaten Gresik. Skripsi. Malang: Universitas Muhammadiyah Malang.

Moleong, L. (2011). Metodologi Penelitian Kualitatif. Bandung: Rosdakarya. 2010. Metodologi Penelitian Kualitatif. Bandung: Rosdakarya.

Nurgiyantoro, B. (2010). Sastra anak: Pengantar pemahaman dunia anak. Yogyakarta: Gadjah Mada University Press.

Parera, J.D. (2009). Dasar-dasar analisis sintaksis. Jakarta: Erlangga.

Suhardi and Candra. (2012). Analisis tema dalam sajak-sajak Gusmarni Zulkifli. Jurnal Dinamika Maritim. Tanjungpinang: Universitas Maritim Raja Ali Haji.

Sukini. (2010). Sintaksis sebuah panduan praktis. Surakarta: Yuma Pustaka.

Wijayanti, S.H. (2013). Bahasa Indonesia dan penyajian karya ilmiah. Jakarta: Raja Grafindo Persada. 